\title{
Effects of herbivore grazing on the physiognomy of the coralline alga Spongites yendoi and on associated competitive interactions
}

G. W. Maneveldt* \& D. W. Keats

*E-mail: gmaneveldt@uwc.ac.za

Department of Biodiversity and Conservation Biology, University of the Western Cape, P. Bag X17, Bellville 7535, South Africa

\section{Abstract}

The territorial gardening limpet Scutellastra cochlear occurs along the south and southern west coasts of South Africa, while one of its primary food items, the encrusting coralline alga Spongites yendoi, extends much further north along the west coast. A combined analysis of geographic variation in limpet grazing frequency and a limpet-manipulation experiment was used to study the interaction between the limpet and its coralline food. The coralline comprised most (c. $85 \%$ ) of the limpet's diet while fleshy algae from the limpet's garden comprised c. $7 \%$. Grazing caused the thallus of the coralline to be thin and smooth; in the absence of herbivory, or under low grazing frequencies, the crust became thick and highly protuberant. Grazing weakened the coralline's interference (overgrowth) competitive ability and also reduced its fecundity. In spite of these two apparently negative impacts, the intimate herbivore-coralline association between S. cochlear and S. yendoi showed characteristics of a facultative mutualism. Grazing by S. cochlear reduces the 
coralline's thallus thickness and consequently increased its lateral margin extension rate. Thinner forms of the coralline grew $5 \mathrm{X}$ faster than thicker forms. An increased lateral growth results in the thinner form of the coralline being very abundant on south and southern west coasts, occupying as much as $79 \%$ of the substratum in the lower eulittoral zone. Thinner forms of S. yendoi were also less burrowed by boring organisms and more strongly attached than thicker forms of the coralline. Grazing by S. cochlear has thus conferred the advantages of faster lateral growth (i.e. success at exploitation competition) and stronger attachment. The coralline and fleshy algae from the limpet's garden were equally high in organic content on a volume basis. This suggests that the crude food value per bite in the coralline and fleshy algae is comparable. This study has shown that incompletely overlapping distributions between strongly interacting species along a broad geographical gradient is not just a significant feature of the ecology of terrestrial, but also of marine ecosystems.

Keywords/Phrases: herbivore-coralline association, herbivory, coralline, limpet, growth, competition, fecundity, morphology, Scutellastra cochlear, South Africa, Spongites yendoi.

\section{Introduction}

With notable exceptions (e.g. Wethey 1983, Hay and Gaines 1984, Dethier and Duggins 1988, Foster 1990, Schaff et al. 1992, Kennelly and Underwood 1993, Bustamante et al. 1995, Jenkins et al. 2000, 2001, 2005, Coleman et al. 2006), ecologists rarely study interactions over very large spatial scales. As a result, biotic interactions along large geographic gradients remain a little explored area of ecology and generalizations from small-scale studies have been applied to entire regions to explain certain observed patterns (Kennelly and Underwood 1993). The purpose of 
this research was to examine a strong interaction between a limpet and its coralline algal food at three widely separated sites along the South African west coast.

Encrusting coralline algae are important occupiers of space in rocky marine environments, yet there have been relatively few studies of interactions involving them with most discussing such interactions from several biogeographically distinct localities (Adey and McIntyre 1973, Paine 1984, Steneck 1983, 1985, 1986, Dethier et al. 1991, Steneck et al. 1991, Keats et al. 1993, 1994a, 1994b, Keats and Maneveldt 1994, Steneck and Dethier 1994, Fujita 1999, Maneveldt et al. 2006). Encrusting algae usually show distinct competitive hierarchies in which thick crusts and those with raised margins are superior interference (overgrowth) competitors to thinner crusts and those with adherent margins (Paine 1984, Steneck 1986, Steneck et al. 1991, Keats and Maneveldt 1994, Morcom et al. 1997). The nature of the competitive hierarchy can, however, change in relation to the abundance of excavating herbivores and the intensity of their grazing (Quinn 1982, Paine 1984, Steneck 1985, Dethier et al. 1991) and some herbivores have been shown to increase lateral margin expansion (exploitation competition) in algal crusts, allowing thinner ones to obtain high cover abundances on shores with high grazing intensities (Steneck et al. 1991). One observation common to many studies is that encrusting coralline algae often thrive under, and have even been postulated to require intense herbivory, particularly from limpets (Adey 1973, Steneck 1983, Breitburg 1984, Sousa and Connell 1992, Dethier 1994, Steneck and Dethier 1994).

Limpets (Mollusca, Gastropoda) are important grazers and many of them include encrusting coralline algae in their diets (Day 1969, Branch 1971, 1981, Steneck 1983, 1986, Steneck and Watling 1982, Paine 1984, Steneck and Paine 1986, Steneck et al. 
1991, Fujita 1992, Maneveldt et al. 2006). Some are even known to form associations with encrusting coralline algae, affecting the morphologies of their coralline prey (Steneck and Paine 1986, Steneck et al. 1991).

The south and west coasts of South Africa are characterised by a shore that has been divided into four zones: the supralittoral fringe (Littorina-zone), the upper eulittoral zone (upper balanoid zone), the mid-eulittoral zone (lower balanoid zone), and the lower eulittoral zone (the 'cochlear-zone' along the south coast, the 'cochlearargenvillei-zone' along the west coast) (Day 1969, Branch and Branch 1988). The territorial gardening limpet Scutellastra cochlear (Born) and the encrusting coralline alga Spongites yendoi (Foslie) Chamberlain are the most characteristic species of the lower eulittoral zone (Figure 1). The distributions of these two species overlap to a large extent (see Branch et al. 1994) with both organisms reaching their highest abundances along the south and southern west coasts (Day 1969, Branch 1976, Branch and Griffiths 1988, Chamberlain 1993, Maneveldt et al. 2008). Scutellastra cochlear characteristically dominates the lower eulittoral zone, often achieving densities of over 3600 individuals per $\mathrm{m}^{2}$ (Branch and Griffiths 1988). At densities above 300 individuals per $\mathrm{m}^{2}$, the limpet excludes most low shore species, except for S. yendoi and a garden of either Gelidium micropterum Kuetzing or Herposiphonia heringii (Harvey) Falkenberg (Branch 1975, 1976, Keats et al. 1994b). Northward along the west coast, however, S. cochlear is progressively replaced by the larger S. argenvillei (Krauss), which may also occur in very dense populations (Branch and Griffiths 1988).

At the southern extreme of its range, S. yendoi is extremely thin while north of Groenriviermond a thick, protuberant form of this coralline is observed. Variation in 
the abundance of S. cochlear appears to have various implications to the physiognomy and ecology of S. yendoi, possibly producing the two forms of the coralline. Here we test the hypothesis that the importance of grazing in determining physiognomic characteristics and competitive success of the coralline alga S. yendoi, differs along a latitudinal gradient in response to S. cochlear densities.

\section{Materials and Methods}

\section{Description of study sites}

This study was conducted within the lower eulittoral zone at three sites from the northern to the southern west coast of South Africa. The study sites included Holbaaipunt ( $\left.18^{\circ} 50^{\prime} 50.7^{\prime \prime} \mathrm{E}, 34^{\circ} 22^{\prime} 50.5^{\prime \prime} \mathrm{S}\right)$ along the southern west coast, Groenriviermond ( $\left.17^{\circ} 34^{\prime} 32.8^{\prime \prime} \mathrm{E}, 30^{\circ} 51^{\prime} 29.2^{\prime \prime} \mathrm{S}\right)$ along the central west coast and Port Nolloth ( $16^{\circ} 51^{\prime} 18.3^{\prime \prime}$ E, $29^{\circ} 14^{\prime} 28.4^{\prime \prime}$ S) along the northern west coast (Figure 2). At Holbaaipunt the lower eulittoral zone is dominated by S. cochlear and a very thin form of S. yendoi in present. Occasionally some thicker forms of S. yendoi are found in very localised areas that lack S. cochlear; these were notably vertical overhangs. At Groenriviermond there is an almost 1:1 relationship between S. cochlear and S. argenvillei in the lower eulittoral. Here too a relatively thin form of S. yendoi is most abundant, with occasional thicker forms of the coralline only occuring between limpet territories. At Port Nolloth the lower eulittoral is dominated almost exclusively by S. argenvillei and only thick forms of the coralline were observed.

\section{General methods}

Field collections were made from all sites, around the same time. Plants were examined fresh when possible or were air dried, or fixed in $10 \%$ commercial 
Formalin in seawater ( $4 \%$ formaldehyde) and stored in $70 \%$ ethanol: $10 \%$ glycerol: $20 \%$ distilled water solution. For light microscopy, preserved thalli were decalcified in $10 \%$ nitric acid, hardened in $70 \%$ ethanol, and sectioned at a thickness of 10-30

$\mathrm{m}$ on a Leitz $\mathrm{CO}_{2}$ freezing microtome. Sections were mounted on a microscope slide containing aniline blue in $60 \%$ Karo syrup. Observations and thallus measurements were compared with those of Chamberlain (1993) for identification. For scanning electron microscopy (SEM), air-dried material was mounted whole or fractured and mounted on stubs, using double-sided adhesive tabs (Agar Scientific, 66a Cambridge Rd., Stanstead, Essex CM24 8DA, UK). The stubs were stored in a desiccator for at least $24 \mathrm{hrs}$ prior to examination, coated with gold for 4-6 min in a 5000-V Edwards S150B sputter coater (Edwards High Vacuum, Manor Royal, Crawley, West Sussex RH10 2LW, UK) and examined at $25 \mathrm{KV}$ with a Hitachi X650 scanning electron microscope (Hitachi, Ltd., Tokyo, Japan), equipped with a Mamiya $6 \mathrm{X}_{7}$ camera.

All measurements are presented as means \pm SE. Differences were evaluated according to " $\mathrm{T}$ "- test for pairs and one-way ANOVA for 3 means. All results were considered statistically significant at $\mathrm{P}<0.05$.

\section{Abundances}

To estimate the cover abundances of S. yendoi and S. cochlear, a 30 x $30 \mathrm{~cm}$ clear acrylic quadrat perforated by 100 holes was held above the substratum and the organism under each hole identified (1 \% increments). Quadrats $(\mathrm{N}=$ $12 /$ transect/site) were laid randomly along three $20 \mathrm{~m}$ transect lines running more or less parallel to the shore. 


\section{Grazing on Spongites yendoi}

To determine the principal grazers of S. yendoi, all grazers found in the same zone as the coralline were collected for gut content analysis. This analysis was only performed at Holbaaipunt where the thinnest form of S. yendoi was found. Grazers comprised the limpets S. cochlear, S. argenvillei, S. granularis (Linnaeus) and the chiton, Acanthochiton garnoti (Blainville). The entire gut of 20 individuals from each of the herbivores was dissected. Using a stereo-microscope equipped with an eyepiece quadrat divided into 100 squares, the percentage of coralline algae, G. micropterum (only in the case of S. cochlear) and other food items found in the foregut was estimated; coralline 'chalk' in the posterior part of the gut was not included. Grazing frequency was measured in the field by recording the number of graphite dots (2 $\mathrm{mm}$ in diameter) removed (sensu Steneck et al. 1991) from the surface of S. yendoi by S. cochlear over time. This was recorded daily for 2 days; graphite dots removed by limpets were marked again each day in the same place. Grazing intensity (= bite depth; sensu Steneck et al. 1991) was measured under a SEM. The average bite depth from each of 10 fragments of S. yendoi from each site was examined.

\section{Morphology, thallus thickness, growth and fecundity}

To determine the effects of grazing on the general physiognomy of S. yendoi, various morphological data were obtained. Under a dissecting microscope the number of protuberances per $\mathrm{cm}^{2}$, and the protuberance heights and diameters were measured. Protuberance percentage cover of the planar area of the thallus was also measured using a dissecting microscope equipped with an eyepiece quadrat divided into 100 small squares. Averages per specimen were first obtained and then the mean for 10 specimens was calculated. 
For margin and thallus thickness measurements of S. yendoi, air-dried material was used. Crude sections were made perpendicular to the growing margins simply by breaking the crusts between two forceps or using a diagonal cutters or a hammer and chisel. The thickness of the margins and thalli were measured under a dissecting microscope equipped with an eyepiece micrometer. Again, averages per specimen were first obtained and then the mean for 10 specimens was calculated.

Marginal extension rates of S. yendoi from all sites were monitored every 10 weeks over a 12-month period, including the occasional thicker forms at Holbaaipunt and Groenriviermond. Extension was measured in relation to two screws, one within the alga and one beyond the margin. Holes drilled were away from the margin being measured to avoid wounding effect influencing growth estimation. The advance of the leading edge of the crust from the tagged screw, indicating growth, was measured to the nearest 0.05 of a millimetre using callipers ( $n=25$ at each site).

To determine the effects of grazing on the fecundity of S. yendoi, a dissecting microscope equipped with an ocular lens quadrat was used. The number of conceptacles across a $0.25 \mathrm{~cm}^{2}(0.5 \mathrm{~cm} \mathrm{X} 0.5 \mathrm{~cm})$ area of the crust was measured. An average of three squares for each specimen was measured and an average for 10 specimens from each site was obtained. Tetrasporangial (asexual) conceptacle morphology and anatomy was also examined to determine the relative impact of grazing at the micro level. Here, only plants from Holbaaipunt (grazed) and Port Nolloth (ungrazed) were examined ( $\mathrm{n}=30$ plants from each site).

\section{Competitive ability}


For competitive interactions, approximately 1200 contact zones between species pairs were sampled along transect lines at all sites (sample sizes for each species pair are reported with the data in Figure 9). The overgrowth (symbol ">" on graph) of one species by another was scored as a "win" for the overgrowing species against the overgrown species (Steneck et al. 1991). Retaliations were also recorded where species normally overgrown resisted overgrowth or reversed the normal pattern by regenerating margins and thereby raising their thalli over the encroaching alga (e.g. symbol A $><$ B on graph: A overgrows B, but B retaliates to overgrowth by A; see Keats and Maneveldt 1994). To determine crust thickness at the point of overgrowth, 10 fragments of the margins of each species involved in a competitive interaction were collected. The competitors' margins were fractured (as described above) perpendicular to the line of contact and their thallus thickness at the point of overgrowth measured.

\section{Attachment strength and percent burrowed}

Ten separate pieces of rock covered by each of the thin and thick forms of S. yendoi from Holbaaipunt and Port Nolloth respectively were chipped off and returned to the laboratory. A high strength Pratley Quickset epoxy glue was used to attach wire paperclips to the bits of coralline from each of the above samples. Using a portable fishing spring-balance attached to the wire paperclips, the force at which the coralline was pulled free from the rock substratum was recorded. Thereafter, the undersurfaces of the individual crusts were examined under a dissecting microscope equipped with an eyepiece micrometer with 100 scale bars. Using the scale bars as a "transect" across the thallus undersurface, the degree of burrowing and undercutting by invertebrates was estimated. A scale bar crossing a point that was undercut was taken as $1 \%$ undercutting. The mean thallus thickness of the individual crusts was 
then determined to compare thallus thickness against attachment strength and percent burrowing.

\section{Organic matter content per bite}

An analysis of the nutrient status of both the thin and thick forms of S. yendoi from Holbaaipunt and Port Nolloth respectively was determined and compared against that of G. micropterum. This was done by measuring their organic content on a volume basis $(\mathrm{n}=10)$. Samples were dry ashed for 16 hours at $450^{\circ} \mathrm{C}$ in a Naber L47T muffle furnace (Naber Industrieofenbau, 2804 Liliethal/Bremen, West Germany) to determine their ash free dry weights (AFDW).

\section{Experimental manipulation}

A portion of randomly selected territories of S. cochlear at Holbaaipunt was cordoned off by sinking screws into the substratum (Figure 3). The distance between screws was sufficiently close to prevent the resident limpet from having access to the cordoned off portion of its territory. This cordoned off portion represented an area of reduced ("o") grazing. Scutellastra cochlear territories are very stable (Branch and Newell 1978) and although territories of adjacent limpets are known to touch, they do not overlap. For this reason we assumed that adjacent limpets have a low probability of detecting the absence of a limpet restricted to the far end of its territory and would subsequently not graze into that limpets' "o" grazing portion. Any error resulting from a failure of this assumption would be conservative. The remaining uncordoned portion should receive more than normal grazing ("2X") since the area was essentially "halved". Measurements recorded from the "o" and " $2 X$ " grazing treatments were independent of each other. A set of unmanipulated limpet territories acted as the controls ("X" level of grazing). Twenty (20) interspersed 
replicates of each of the three experimental conditions were set up. All S. yendoi within the experimental design were initially smooth crusts, already grazed by S. cochlear. After five months the general physiognomy, thallus and margin thickness, and marginal extension (every month) of S. yendoi were recorded.

\section{Results}

\section{Abundances}

There was a strong correlation $(\mathrm{r}=0.90 ; \mathrm{P}<0.01 ; \mathrm{n}=36$ quadrats per site $)$ between S. cochlear and S. yendoi's percent cover abundance in the lower eulittoral zone (data pooled from the three sites; Figure 4). Spongites yendoi achieved its highest cover abundance at Holbaaipunt $(78.97 \% \pm 2.88)$ and its lowest at Port Nolloth (2.99 \% \pm 1.43). Spongites yendoi's cover abundance at Groenriviermond was somewhat patchy as much of the primary substratum was occupied by another encrusting coralline alga, Leptophytum foveatum Chamberlain and Keats (pers. obs.). While the encrusting brown alga, Ralfsia verrucosa (Areschoug) J. Agardh, occupied much of the ungrazed space between limpet territories along the southern west coast (Figure 1), another encrusting coralline alga, Spongites impar (Foslie) Chamberlain, was characteristically the most abundant encrusting alga between limpet territories along the southwest coast between Holbaaipunt and Groenriviermond (pers. obs.).

\section{Grazing on Spongites yendoi}

Spongites yendoi comprised most (c. $85 \%$ ) of S. cochlear's diet, while fleshy algae from the limpet's garden comprised only c. $7 \%$ (Table 1 ). The remaining c. $8 \%$ of the gut contents of S. cochlear comprised a mixture of diatoms, invertebrates, microscopic algae and unidentifiable material. The amount of S. yendoi in the gut of 
S. cochlear was substantially higher than in any of the other herbivores (Table 1).

At Holbaaipunt, significantly more (c. $87 \%$ ) of the surface of S. yendoi was grazed than at Groenriviermond (c. 55 \%) (Table 2). The grazing frequencies at Port Nolloth were so low that even after $48 \mathrm{hrs}$ the graphite dots were still visible on the surfaces of the coralline. There was no difference in the grazing intensities experienced at Holbaaipunt and Groenriviermond (Table 2).

\section{Morphology, thallus thickness, growth and fecundity in natural populations}

Spongites yendoi thalli at Port Nolloth without S. cochlear, were more protuberant than either the Holbaaipunt or Groenriviermond populations (Figure 5, Table 2). Protuberances covered a larger percentage of the thallus of thicker S. yendoi and the protuberance height and diameter was substantially greater at Port Nolloth (Table 2). Both the margins and the thalli in the Holbaaipunt and Groenriviermond populations of S. yendoi were extremely thin compared to the Port Nolloth population (Table 2).

The thin form of S. yendoi from Holbaaipunt $\left(0.59 \pm 0.11 \mathrm{~mm} . \mathrm{month}^{-1}\right)$ grew laterally faster than both the thin form from Groenriviermond ( $0.38 \pm 0.07$ mm.month $\left.{ }^{-1}\right)$ and the thick form from Port Nolloth $\left(0.10 \pm 0.02 \mathrm{~mm}^{\mathrm{m} m o n t h}{ }^{-1}\right)(\mathrm{P}<0.01)$ (Figure 6). There was a strong negative correlation between thallus thickness and lateral margin extension rates $(r=-0.90, P=0.02)($ Figure 7$)$.

Populations of S. yendoi growing in the absence of S. cochlear had a greater number of conceptacles per unit planar area than those experiencing grazing (Table 2). The 
conceptacle dimensions of the coralline located within S. cochlear grazed areas were generally smaller than those of S. yendoi occurring outside of the limpets' grazing range (Table 3). Even the shape of the conceptacles differed with respect to the presence or absence of grazing.

\section{Morphology, thallus thickness, growth and fecundity in response to manipulated grazing}

Under reduced grazing conditions ("o" grazing) the margins and thalli of S. yendoi became thicker and the thalli very protuberant upon limpet exclusion (Table 4). Even the fecundity under the different experimental designs differed dramatically, with the number of conceptacles being extremely low under increased ("2X") grazing pressure $(\mathrm{P}<0.01$, Table 4). Under increased grazing (“2X" grazing $-1.19 \pm 0.22$ mm.month ${ }^{-1}$ ) pressure, the coralline grew significantly faster than under either control ("X" grazing - $0.57 \pm 0.04 \mathrm{~mm} . \mathrm{month}^{-1}$ ) or reduced grazing ("o" grazing $\left.0.10 \pm 0.03 \mathrm{~mm} . \mathrm{month}^{-1}\right)$ conditions $(\mathrm{P}<0.01)($ Figure 8$)$.

\section{Competitive ability}

At Holbaaipunt, with a relatively high cover of S. cochlear, S. yendoi was ranked below R. verrucosa in the competitive hierarchy. Most (93\%) of the competitive interactions between the two crusts involved R. verrucosa overgrowing S. yendoi (Figure 9). At Groenriviermond, with a reduced cover of S. cochlear, the coralline was ranked above R. verrucosa in the competitive hierarchy. Here $57 \%$ of all competitive interactions between the two crusts involved S. yendoi overgrowing R. verrucosa (Figure 9). No competitive interactions between the two crusts were found at Port Nolloth where S. cochlear is absent. Here S. yendoi mostly occured in the mid eulittoral zone and did not compete with R. verrucosa for space. At two of the three sites (Holbaaipunt: $\mathrm{r}=0.98, \mathrm{P}<0.01$; Groenriviermond: $\mathrm{r}=0.99, \mathrm{P}<$ 
0.01; Port Nolloth: $\mathrm{r}=0.95, \mathrm{P}=0.10$ ), thallus thickness was positively correlated with rank in overgrowth competition.

\section{Attachment strength and percent burrowed}

Thick forms of S. yendoi from Port Nolloth showed a high degree of burrowing and a weak attachment strength (Table 5). In contrast, thin forms from Holbaaipunt and Groenriviermond showed almost no burrowing and much higher attachment strengths. Here too there was a strong (negative) correlation between thallus thickness and attachment strength $(\mathrm{r}=-0.90 ; \mathrm{P}<0.01 ; \mathrm{n}=10$ crusts per site $)$.

\section{Organic matter content per bite}

There was no statistical difference in the organic content (as AFDW) on a volume (per bite) basis for both the thin (0.299 \pm 0.018 g.ml-1; Holbaaipunt and Groenriviermond pooled) and thick (0.294 \pm 0.019 g.ml-1; Port Nolloth) forms of S. yendoi and G. micropterum (0.304 \pm 0.008 g.ml-1; from Holbaaipunt $)(P=0.86)$. In G. micropterum much of this volume is water while in S. yendoi it is calcium carbonate.

\section{Discussion}

\section{Summary of main findings}

Herbivory may have positive effects on the grazed plants and studies involving encrusting coralline algae have shown that some corallines benefit from their associations with herbivores (e.g. Steneck and Adey 1976, Steneck et al. 1991, Littler et al. 1995, Stachowics and Hay 1996, Wai and Williams 2005). Many studies have also shown that coralline abundance is often positively correlated with that of their grazers (Adey and Macintyre 1973, Branch 1975, Steneck 1985, Littler et al. 1995, Wai 
and Williams 2005). Grazing by S. cochlear reduced the thallus thickness of the coralline alga S. yendoi and in so doing increased its lateral growth and reduced its susceptibility to boring organisms. These factors appear to have resulted in an increase in the cover abundance of the coralline on shores dominated by the limpet. If space is available for growth, or if it is continually renewed, a thin crust with a fast lateral growth should rapidly dominate the shore (Keats and Maneveldt 1994, Wai and Williams 2005). We have shown differential grazing frequencies to be responsible for the differences in thallus thickness and lateral growth in S. yendoi.

The varying grazing frequencies of S. cochlear are the main cause for the differences in thallus thickness and external morphology of the coralline. We have shown these patterns to exist on a large geographical scale and have been able to duplicate them locally by manipulating grazing by S. cochlear. Several studies have shown that grazing may affect the thallus thickness and the morphology of encrusting coralline algae (Steneck and Adey 1976, Steneck and Watling 1982, Steneck 1983, 1985, 1986, Steneck and Paine 1986, Steneck et al. 1991, Littler et al. 1995), some advocating that both grazing intensity (bite depth) and frequency are of particular importance (Steneck 1983, Steneck and Watling 1982, Steneck et al. 1991). Our results, however, suggest that within the lower eulittoral on South African west coast shores, differences in grazing frequency are of greater consequence than intensity.

\section{Morphological consequences of grazing}

The genetic disposition of S. yendoi is to produce a lumpy to protuberant crust. Grazing by S. cochlear appears primarily responsible for the occurrences of smooth plants. This finding is supported by Y. M. Chamberlain (pers. comm.) who found that populations of S. yendoi north of Richards Bay (the northern limit of the 
geographic extent of S. cochlear along the east coast) were sparse, patchy, thick and protuberant.

Scutellastra cochlear also affected the reproductive output of the coralline. Since grazing reduced the number of protuberances, there was less surface area for conceptacle production. Although natural ("X") grazing frequencies were not sufficient to completely remove the conceptacles, under higher grazing pressures (" $2 X$ " grazing), the limpet was capable of denuding the coralline's surface of its conceptacles. Furthermore, grazing even altered the size, shape and internal dimensions of the conceptacles (Table 3). Since tetrasporangia in Spongites spp. characteristically develop at the periphery of the conceptacle chamber (Chamberlain 1993), any factor reducing the internal conceptacle diameter would invariably also reduce the number of tetrasporangia produced. This no doubt has a bearing on the reproductive output. Steneck and Adey (1976) similarly demonstrated that the encrusting coralline alga Lithophyllum congestum (Foslie) Foslie produced protuberances when it occurred on the edges of reef flats where fish feeding was reduced. When compared with the encrusting form, this protuberant form also had a higher reproductive output. One might argue then that the genetic diversity in such plants would be greater in infrequently or ungrazed areas because such areas would be dominated by more sexually and less vegetatively reproducing individuals.

Thinner crusts generally grow faster than thicker crusts (Steneck 1985, 1986, Keats et al. 1994b Wai and Williams 2005). Thicker crusts maintain more living nonphotosynthetic cells than do thinner crusts (Steneck 1983) and it is believed that this investment in vertical expansion depletes photosynthates that could be used for lateral expansion (Steneck 1985). Alternatively, corallines store energy in their lower 
cells and thicker corallines may simply be directing more energy into storage. Both geographic observations and limpet manipulation experiments clearly show that thinner S. yendoi grow faster than thicker ones. Although the margin thickness of the dominant forms of S. yendoi from Holbaaipunt and Groenriviermond do not differ, their thallus thickness and lateral growth do. This suggests that lateral expansion is a function of the thallus thickness. In addition, sloughing of the outer layers of cells in corallines such as $\mathrm{S}$ yendoi was suggested to be an effective way of remaining thin because it presumably allowed for faster lateral growth (Keats et al. 1994b). The present study has shown that grazing by S. cochlear, rather than deep-layer sloughing (see Keats et al. 1993), is primarily responsible for the thinning of the thallus of S. yendoi. Furthermore, we have observed the thick form of S. yendoi at Port Nolloth undergoing sloughing which also negates the suggestion that deep-layer sloughing could be an effective way of remaining thin.

\section{Interactions}

Success in overgrowth (interference) competition between encrusting algae is largely determined by the thallus thickness and the raising of the margin (Steneck 1985, 1986, Steneck et al. 1991, Keats and Maneveldt 1994, Keats et al. 1994a, Morcom et al. 1997). Any factor, therefore, that affects the crust thickness of competing species, may mediate their competitive success. Grazing by S. cochlear reduces the margin and thallus thickness of S. yendoi and consequently affects its competitive (interference) ability. There is a potential for a complete competitive reversal between R. verrucosa (a thicker, superior competitor to S. yendoi along the southern west coast [Keats et al. 1994a]) and S. yendoi at Port Nolloth. The tendency for this competitive reversal already exists at Groenriviermond (Figure 9). A complete competitive reversal does, however, not occur at Port Nolloth since these two species 
do not interact there. Additional monitoring sites north of Groenriviermond are therefore required to fully evaluate the competitive interaction between S. yendoi and R. verrucosa.

Thick corallines are known to be more susceptible to invasion from boring organisms (Paine 1984, Steneck 1986, Steneck and Paine 1986, Keats et al. 1994b). Keats et al. (1994b) have shown that the thicker L. ferox, which was much more heavily burrowed than the thinner S. yendoi, was more weakly attached. We have shown that the thicker, more protuberant form of S. yendoi has a weaker attachment than the thinner form because of its greater susceptibility to invasion by boring organisms. The slow lateral growth and weaker attachment of the thicker form are probably the reasons for the low cover abundance of the coralline at Port Nolloth.

Although gut contents of S. cochlear comprised almost solely S. yendoi, it has been stated that production and energy content of S. yendoi (as Lithothamnion) is so low that it cannot alone support the energetic needs of S. cochlear (Branch 1980, Branch and Griffiths 1988). Branch (1980) further stated that the gardens of red algae thus seem vital for the densely packed S. cochlear and although they often form only a small fringe around each animal, their production and energy contents are high. Our results show that $\mathrm{S}$. yendoi is as high in its organic content on a volume (per bite) basis as G. micropterum. This is supported by other research (e.g. Maneveldt et al. 2006, M. E. Hay and Q. E. Kappel pers. comm.) that have shown many corallines to be high in organic content (per volume) relative to many fleshy algae. It is thus not hard to see why juvenile S. cochlear, and adult limpets lacking gardens, survive almost exclusively on a diet of S. yendoi (as Lithothamnion), an observation long ago made by Day (1969). It may be that the coralline and the garden of fine red algae are 
fulfilling different energy requirements and that larger S. cochlear are essentially maintaining a mixed diet of algae (see Kitting 1980, Cruz-Rivera and Hay 2001, 2003). This suggestion, however, needs to be evaluated through further studies.

\section{Concluding remarks}

The interaction between the coralline S. yendoi and the limpet S. cochlear shows characteristics of a facultative mutualism, an association not unfamiliar to other South African limpets and encrusting algae (see McQuaid and Froneman 1993) and is summarised in Figure 10. The limpet has an abundant food source that is comparably high in organic content as its garden alga. The corallines' benefits are two-fold: an increased lateral growth (i.e. increased exploitation competitive ability); and an increased attachment strength resulting from a reduction in the corallines susceptibility to invasion from boring organisms. Although there are costs associated with grazing (i.e. low fecundity and weak interference - overgrowth - competitive ability), the above benefits have clearly contributed to the coralline being a very obvious feature along the South African south and southern west coasts. This study has contributed to a growing body of literature showing that grazing can contribute positively to the competitive success and abundance of food species and that incompletely overlapping distributions between strongly interacting species is not just a significant feature of the ecology of terrestrial (e.g. Jachman and Croes 1991, Stuart-Hill 1992, Moolman and Cowling 1994), but also of marine ecosystems.

\section{Acknowledgements}

We thank the Department of Biodiversity and Conservation Biology at the University of the Western Cape (UWC) for providing funding and research equipment and the South African National Research Foundation (NRF) for research grants to GWM and DWK. Special thanks to Robert Steneck who showed us how to manipulate limpets 
and measure lateral growth in encrusting coralline algae. Glenville Arendse, Shaun Davis, and the late Aldridge Groener gave up much of their time to help with fieldwork. A special thanks also to Rodrigo Bustamante and the Zoology Department at the University of Cape Town for the use of their lodging facility at Groenriviermond. George M. Branch, Yvonne M. Chamberlain, Mark E. Hay and Robert S. Steneck provided valuable discussion and comments. We are grateful to the reviewers for comments that greatly improved the quality of this manuscript. 


\section{References}

Adey WH (1973) Temperature control of reproduction and productivity in a subarctic coralline alga. Phycologia 12: 111-118

Adey WH, Macintyre IG (1973) Crustose coralline algae: A re-evaluation in the geological sciences. Geological Society of America Bulletin 84: 883-904

Branch GM (1971) The ecology of Patella Linnaeus from the Cape Peninsula, South Africa. I. Zonation, movements and feeding. Zoologica Africana 6: 1-38

Branch GM (1975) Mechanisms reducing intraspecific competition in Patella spp.: Migration, differentiation and territorial behaviour. Journal of Animal Ecology 44: $575-600$

Branch GM (1976) Interspecific competition experienced by South African Patella species. J ournal of Animal Ecology 45: 507-529

Branch GM (1980) Territoriality in limpets: Manipulation experiments and energy budgets. J ournal of the Malacological Society of Australia 4: 245-246

Branch GM (1981) The biology of limpets: Physical factors, energy flow, and ecological interactions. Oceanography and Marine Biology: An Annual Review 19: $235-380$

Branch GM, Newell RC (1978) A comparative study of metabolic energy expenditure in the limpets Patella cochlear, P. oculus and P. granularis. Marine Biology 49: $351-361$

Branch GM, Branch M (1988) The living shores of Southern Africa. Struik, Cape Town, $272 \mathrm{pp}$

Branch GM, Griffiths CL (1988) The Benguela Ecosystem part V. The coastal zone. Oceanography and Marine Biology: An Annual Review 26: 395-486

Branch GM, Griffiths CL, Branch ML, Beckley LE (1994) Two Oceans: A guide to the 
marine life of southern Africa. David Philip, Cape Town, 360 pp

Breitburg DL (1984) Residual effects of grazing Inhibition of competitor recruitment by encrusting coralline algae. Ecology 65: 1136-1143

Bustamante RH, Branch GM, Eekhout S, Robertson B, Zoutendyk P, Schleyer M, Dye A, Hanekom N, Keats D, Jurd M, McQuaid C (1995) Gradients of intertidal primary productivity around the coast of South Africa and their relationships with consumer biomass. Oecologia 102: 189-201

Chamberlain YM (1993) Observations on the crustose coralline red alga Spongites yendoi (Foslie) comb. nov. in South Africa and its relationship to S. decipiens (Foslie) comb. nov. and Lithophyllum natalense Foslie. Phycologia 32: 100-115

Coleman RA, Underwood AJ, Benedetti-Cecchi L, Åberg P, Arenas F, Arrontes J, Castro J, Hartnoll RG, Jenkins SR, Paula J, Della Santina P, Hawkins SJ (2006) A continental scale evaluation of the role of limpet grazing on rocky shores. Oecologia 147: 556-564

Cruz-Rivera E, ME Hay (2001) Macroalgal traits and the feeding and fitness of an herbivorous amphipod: the roles of selectivity, mixing and compensation. Marine Ecology Progress Series 218: 249-266

Cruz-Rivera E, ME Hay (2003) Prey nutritional quality interacts with chemical defenses to affect consumer feeding and fitness. Ecological Monographs 73 $(3): 483-506$

Day JH (1969) A Guide to Marine Life on South African Shores. Cape Town, A.A. Balkema, $300 \mathrm{pp}$

Dethier MN (1994) The ecology of intertidal algal crusts: variation within a functional group. J ournal of Experimental Marine Biology and Ecology 177: 3771

Dethier MN, Duggins DO (1988) Variation in strong interactions in the intertidal 
zone along a geographical gradient: A Washington-Alaska comparison. Marine Ecology Progress Series 50: 97-105

Dethier MN, Paull KM, Woodbury MM (1991) Distribution and thickness patterns in subtidal encrusting algae from Washington. Botanica Marina 34: 201-210

Foster MS (1990) Organization of macroalgal assemblages in the Northeast Pacific: the assumption of homogeneity and the illusion of generality. Hydrobiologia 192: 21-33

Fujita D (1992) Grazing on the crustose coralline alga Lithophyllum yessoense by the sea urchin Strongylocentrotus nudus and the limpet Acmaea pallida. Benthos Research 42: 49-54

Fujita D (1999) The sea star Asterina pectinifera causes deep-layer sloughing in Lithophyllum yessoense (Corallinales, Rhodophyta). Hydrobiologia 398/399: 261-266

Hay ME, Gaines SD (1984) Geographic differences in herbivore impact: Do Pacific herbivores prevent Caribbean seaweeds from colonizing via the Panama Canal. Biotropica 16: 24-30

Jachman H, Croes $\mathrm{T}$ (1991) Effects of browsing by elephants on the Combretum/Terminalia woodland at the Nazinga Game Ranch, Burkina Faso, West Africa. Biological Conservation 57: 13-24

Jenkins SR, Åberg P, Cervin G, Coleman RA, Delany J, Della Santina P, Hawkins SJ, LaCroix E, Myers AA, Lindegarth M, Power AM, Roberts MF, Hartnoll RG (2000) Spatial and temporal variation in settlement and recruitment of the intertidal barnacle Semibalanus balanoides (L.) (Crustacea: Cirripedia) over a European scale. J ournal of Experimental Marine Biology and Ecology 243: 209-225

Jenkins SR, Arenas F, Arrontes J, Bussell J, Castro J, Coleman RA, Hawkins SJ, Kay S, Martínez B, Oliveros J, Roberts MF, Sousa S, Thompson RC, Hartnoll RG 
(2001) European-scale analysis of seasonal variability in limpet grazing activity and microalgal abundance. Marine Ecology Progress Series 211: 193-203

Jenkins SR, Coleman RA, Della Santina P, Hawkins SJ, Burrows MT, Hartnoll RG (2005) Regional scale differences in the determinism of grazing effects in the rocky intertidal. Marine Ecology Progress Series 287: 77-86

Keats DW, Maneveldt G (1994) Leptophytum foveatum Chamberlain \& Keats (Rhodophyta, Corallinales) retaliates against competitive overgrowth by other encrusting algae. J ournal of Experimental Marine Biology and Ecology 175:243251

Keats DW, Groener A, Chamberlain YM (1993) Cell sloughing in the littoral zone coralline alga, Spongites yendoi (Foslie) Chamberlain (Corallinales, Rhodophyta). Phycologia 32: 143-150

Keats DW, Matthews I, Maneveldt G (1994a) Competitive relationships and coexistence in a guild of crustose algae in the eulittoral zone, Cape Province, South Africa. South African J ournal of Botany 60: 108-113

Keats DW, Wilton P, Maneveldt G (1994b) Ecological significance of deep-layer sloughing in the eulittoral zone coralline alga, Spongites yendoi (Foslie) Chamberlain (Corallinaceae, Rhodophyta) in South Africa. Journal of Experimental Marine Biology and Ecology 175: 145-154

Kennelly SJ, Underwood AJ (1993) Geographic consistencies of effects of experimental physical disturbance on understory species in sublittoral kelp forests in central New South Wales. Journal of Experimental Marine Biology and Ecology 168: 35-58

Kitting CL (1980) Herbivore-plant interactions of individual limpets maintaining a mixed diet of intertidal marine algae. Ecological Monographs 50: 527-550

Littler MM, Littler DS, Taylor PR (1995) Selective herbivore increases biomass of its 
prey: A chiton-coralline reef-building association. Ecology 76: 1666-1681

Maneveldt GW, Wilby D, Potgieter M., Hendricks MGJ (2006) The role of encrusting coralline algae in the diets of selected intertidal herbivores. Journal of Applied Phycology 18: 619-627

Maneveldt GW, Chamberlain YM, Keats DW (2008) A catalogue with keys to the non-geniculate coralline algae (Corallinales, Rhodophyta) of South Africa. South African J ournal of Botany DOI:10.1016/j.sajb.2008.02.002

McQuaid CD, Froneman PW (1993) Mutualism between the territorial intertidal limpet Patella longicosta and the crustose alga Ralfsia verrucosa. Oecologia 96: $128-133$

Moolman HJ, Cowling RM (1994) The impact of elephant and goat grazing on the endemic flora of South African thicket. Biological Conservation 68: 53-61

Morcom NF, Ward SA, Woelkerling WJ (1997) Competition of epiphytic nongeniculate corallines (Corallinales, Rhodophyta): overgrowth is not victory. Phycologia 36: 468-471

Paine RT (1984) Ecological determinism in the competition for space. Ecology 65 : $1339-1348$

Quinn JF (1982) Competitive hierarchies in marine benthic communities. Oecologia 54: $129-135$

Schaff T, Levin L, Blair N, DeMaster D, Pope R, Boehme S (1992) Spatial heterogeneity of benthos on the Carolina continental slope: large (10okm)-scale variation. Marine Ecology Progress Series 88: 143-160

Sousa WP, Connell JH (1992) Grazing and succession in marine algae. In: John DM, Hawkins SJ, Price JH (eds) Plant-Animal Interactions in the Marine Benthos. Systematics Association Special Volume Number 46. The Systematics Association. Clarendon Press, Oxford, p 425-441 
Stachowicz JJ, Hay ME (1996) Facultative mutualism between an herbivorous crab and a coralline alga: advantages of eating noxious seaweeds. Oecologia 105: 377387

Steneck RS (1983) Escalating herbivory and resulting adaptive trends in calcareous crusts. Paleobiology 9: 44-61

Steneck RS (1985) Adaptations of crustose coralline algae to herbivory: Patterns in space and time. In: Toomy DF, Nitecki MH (eds) Paleoalgology: Contemporary research and applications. Springer-Verlag, Berlin p 352-366

Steneck RS (1986) The ecology of coralline algal crusts: Convergent patterns and adaptive strategies. Annual Review of Ecology and Systematics 17: 273-303

Steneck RS, Adey WH (1976) The role of environment control of morphology in Lithophyllum congestum, a caribbean algal ridge builder. Botanica Marina 19: $197-215$

Steneck RS, Watling L (1982) Feeding capabilities and limitations of herbivorous molluscs: A functional group approach. Marine Biology 68: 299-319

Steneck RS, Paine RT (1986) Ecological and taxonomic studies of shallow-water encrusting Corallinaceae (Rhodophyta) of the boreal northeastern Pacific. Phycologia 25: 221-240

Steneck RS, Dethier MN (1994) A functional group approach to the structure of algaldominated communities. Oikos 69: 476-498

Steneck RS, Hacker SD, Dethier MN (1991) Mechanisms of competitive dominance between crustose coralline algae: An herbivore-mediated competitive reversal. Ecology 72: 938-950

Stuart-Hill GC (1992) Effects of elephants and goats on the Kaffrarian succulent thicket of the eastern Cape, South Africa. J ournal of Applied Ecology 29: 699-710 
Wai T-C, Williams GA (2005) The relative importance of herbivore-induced effects on productivity of crustose coralline algae: Sea urchin grazing and nitrogen excretion. J ournal of Experimental Marine Biology and Ecology 324: 141- 156

Wethey DS (1983) Geographic limits and local zonation: The barnacles Semibalanus (Balanus) and Chthamalus in New England. The Biological Bulletin 165: 330341 
Table 1. The gut contents (\%) of the four herbivores commonly found associated with S. yendoi at Holbaaipunt ( $\mathrm{n}=20$ individuals per herbivorous species). NB. Only S. cochlear grazes on G. micropterum in addition to S. yendoi.

\begin{tabular}{|c|c|c|c|}
\hline Herbivore & $\begin{array}{l}\text { Spongites } \\
\text { yendoi }\end{array}$ & $\begin{array}{l}\text { Gelidium } \\
\text { micropterum }\end{array}$ & Other \\
\hline $\begin{array}{l}\text { Scutellastra cochlear } \\
\text { mean } \pm \text { SE } \\
\text { ANOVA }\end{array}$ & $\begin{array}{l}85.40 \pm 0.58 \\
P<0.01\end{array}$ & $6.75 \pm 0.43$ & $7.85 \pm 0.30$ \\
\hline $\begin{array}{l}\text { Scutellastra } \\
\text { argenvillei } \\
\text { mean } \pm \text { SE } \\
\text { Paired sample T- } \\
\text { test }\end{array}$ & $\begin{array}{l}\mathrm{O} \\
\mathrm{P}<0.01\end{array}$ & $\mathrm{~N} / \mathrm{A}$ & 100 \\
\hline $\begin{array}{l}\text { Scutellastra } \\
\text { granularis } \\
\text { mean } \pm \text { SE } \\
\text { Paired sample T- } \\
\text { test }\end{array}$ & $\begin{array}{l}47.01 \pm 8.60 \\
P=0.63\end{array}$ & $\mathrm{~N} / \mathrm{A}$ & $52.99 \pm 8.60$ \\
\hline $\begin{array}{l}\text { Acanthochiton } \\
\text { garnoti } \\
\text { mean } \pm \mathrm{SE} \\
\text { Paired sample T- } \\
\text { test }\end{array}$ & $\begin{array}{l}25.60 \pm 7.61 \\
P<0.01\end{array}$ & $\mathrm{~N} / \mathrm{A}$ & $74.40 \pm 7.61$ \\
\hline
\end{tabular}


Table 2. Comparison of the grazing frequencies and intensities experienced by S. yendoi and the coralline's differential physiognomy under natural conditions from the three study sites ( $n=10$ unless otherwise stated).

\section{Feature/Site}

\section{Holbaaipunt}

\section{Groenriviermo Port Nolloth} nd

Grazing frequency (percentage of the area grazed every $24 \mathrm{hrs}$ )
mean \pm SE
ANOVA
$86.90 \pm 2.68$
$55.00 \pm 2.95$
o
$\mathrm{P}<0.01$

$\mathrm{n}$

20

18

12

Grazing intensity (bite depth in $\mu \mathrm{m})$
mean $\pm \mathrm{SE}$
Paired sample T-test
$15.40 \pm 0.97$
$14.80 \pm 0.74$
N/A
$\mathrm{P}=0.75$

Protuberance data

Height (in mm)

mean $\pm \mathrm{SE}$

ANOVA

$0.53 \pm 0.16$

$0.58 \pm 0.32$

$2.49 \pm 0.15$

Diameter (in mm)

mean $\pm \mathrm{SE}$

ANOVA

$\mathrm{P}<0.01$

$0.63 \pm 0.17$

$1.04 \pm 0.31$

$2.21 \pm 0.16$

Percent cover

mean $\pm \mathrm{SE}$

ANOVA

$\mathrm{P}<0.01$

$22.98 \pm 5.16$

$74.38 \pm 2.63$

$7.81 \pm 1.89$

$\mathrm{P}<0.01$

Thickness

Margin (in $\mu \mathrm{m}$ )

mean $\pm \mathrm{SE}$

ANOVA

$122.76 \pm 14.23$

$112.86 \pm 15.24$

$\mathrm{P}<0.01$

Thallus (in $\mu \mathrm{m}$ )

mean $\pm \mathrm{SE}$

$190.00 \pm 15.50$

$372.95 \pm 101.63$

1766.73

101.63

$263.34 \pm 22.36$

ANOVA

$\mathrm{P}<0.01$

No. conceptacles per $\mathrm{cm}^{2}$

mean $\pm \mathrm{SE}$

ANOVA

$205.72 \pm 28.57$

$368.12 \pm 41.07$

$\mathrm{P}<0.01$

$650.52 \pm 83.93$

ANOVA 
Table 3. Comparison of the tetrasporangial conceptacle anatomy of S. yendoi under S. cochlear grazed (Holbaaipunt) and ungrazed (Port Nolloth) conditions (n $=30$ ). All measurements are in $\mu \mathrm{m}$.

\section{Feature}

External diameter:

$$
\begin{aligned}
& \text { range } \\
& \text { mean } \pm \mathrm{SE}
\end{aligned}
$$

Paired sample T-test

Chamber diameter:

range
mean $\pm \mathrm{SE}$

Paired sample T-test

Chamber height:

$$
\text { range }
$$

mean $\pm \mathrm{SE}$

Paired sample T-test

Roof thickness:

range
mean $\pm \mathrm{SE}$
Paired sample T-test

Shape
S. cochlear grazed

$$
\begin{aligned}
& 200-406 \\
& 287.55 \pm 18.64 \\
& P<0.01
\end{aligned}
$$

$$
\begin{aligned}
& 280-780 \\
& 544.46 \pm 45.29
\end{aligned}
$$

S. cochlear ungrazed

$136-280$

$203.18 \pm 13.65$

$\mathrm{P}<0.01$

$63-120$

$91.67 \pm 4.51$

$\mathrm{P}<0.01$

$63-158$

$122.75 \pm 8.63$

$142-328$

$282.64 \pm 16.58$

$30-78$

$37-78$

$53.91 \pm 4.46$

$\mathrm{P}<0.01$

$65.18 \pm 3.52$

low domed

conical 
Table 4. Comparison of S. yendoi's physiognomy under the three experimental conditions. "O" grazing = substantially reduced grazing conditions; " $\mathrm{X}$ " grazing = natural grazing (control) conditions; " $2 \mathrm{X}$ " grazing = greater than natural grazing conditions $(n=10$; averages for each $\mathrm{S}$. yendoi fragment from each of the three experimental conditions were first obtained and then the mean for 10 fragments was calculated).

\begin{tabular}{|c|c|c|c|}
\hline Feature & “2X” grazing & "X" grazing & “0” grazing \\
\hline \multicolumn{4}{|c|}{ Protuberance data } \\
\hline \multicolumn{4}{|c|}{ Height (in mm) } \\
\hline mean $\pm \mathrm{SE}$ & $0.22 \pm 0.06$ & $0.6 \pm 0.09$ & $0.56 \pm 0.09$ \\
\hline ANOVA & $\mathrm{P}<0.01$ & & \\
\hline \multicolumn{4}{|c|}{ Diameter (in mm) } \\
\hline mean $\pm \mathrm{SE}$ & $0.36 \pm 0.09$ & $0.64 \pm 0.09$ & $0.68 \pm 0.05$ \\
\hline ANOVA & $\mathrm{P}<0.01$ & & \\
\hline \multicolumn{4}{|l|}{ Percent cover } \\
\hline mean $\pm \mathrm{SE}$ & $4.40 \pm 1.33$ & $10.30 \pm 1.81$ & $46.90 \pm 1.90$ \\
\hline ANOVA & $\mathrm{P}<0.01$ & & \\
\hline \multicolumn{4}{|l|}{ Thickness } \\
\hline \multicolumn{4}{|c|}{ Margin (in $\mu \mathrm{m}$ ) } \\
\hline mean $\pm \mathrm{SE}$ & $121.75 \pm 11.20$ & $118.50 \pm 11.20$ & $224.55 \pm 15.20$ \\
\hline ANOVA & $\mathrm{P}<0.01$ & & \\
\hline \multicolumn{4}{|c|}{ Thallus (in $\mu \mathrm{m}$ ) } \\
\hline mean $\pm \mathrm{SE}$ & $140.00 \pm 12.00$ & $246.50 \pm 14.00$ & $636.80 \pm 20.00$ \\
\hline ANOVA & $\mathrm{P}<0.01$ & & \\
\hline \multicolumn{4}{|c|}{$\begin{array}{l}\text { No. conceptacles per } \\
\mathrm{cm}^{2}\end{array}$} \\
\hline mean $\pm \mathrm{SE}$ & $45.20 \pm 9.94$ & $222.80 \pm 19.89$ & $416.00 \pm 34.09$ \\
\hline ANOVA & $\mathrm{P}<0.01$ & & \\
\hline
\end{tabular}


Table 5. Parameters associated with attachment strength for both thin (Holbaaipunt and Groenriviermond pooled) and thick (from Port Nolloth) S. yendoi ( $\mathrm{n}=$ 10 plants per site).

\begin{tabular}{lll}
\hline Feature & Thin form & Thick form \\
\hline $\begin{array}{l}\text { Thallus Thickness (in } \mu \mathrm{m}) \\
\text { mean } \pm \text { SE }\end{array}$ & $\begin{array}{l}190.04 \pm 15.50 \\
\text { Paired sample T-test }\end{array}$ & $2019.03 \pm 154.50$ \\
$\begin{array}{l}\text { Percentage burrowed } \\
\text { mean } \pm \text { SE }\end{array}$ & $\begin{array}{l}\text { P } \\
\text { Paired sample T-test }\end{array}$ & $\mathrm{P}<0.01$ \\
$\begin{array}{l}\text { Removal force (in kg) } \\
\text { mean } \pm \text { SE } \\
\text { Paired sample T-test }\end{array}$ & $\begin{array}{l}7.20 \pm 0.38 \\
\mathrm{P}<0.01\end{array}$ & $78.60 \pm 2.18$ \\
\hline
\end{tabular}

\section{Figure Captions}

Figure 1. The territorial gardening limpet S. cochlear dominates the lower eulittoral zone along with the encrusting coralline alga, S. yendoi. Territories of adjacent limpets are known to touch but do not overlap, as indicated by narrow strips of R. verrucosa (A) between territories, apparently ungrazed by S. cochlear.

Figure 2. Map of the location of study sites along the South African west coast.

Figure 3. The method of using tagged and untagged screws to measure lateral margin extension in encrusting algae and for manipulating limpets. Side (A) of the screws represents the reduced ("o") grazing portion while side (B) represents the increased ("2X") grazing portion. The natural, unmanipulated state acted as the control.

Figure 4. Spongites yendoi and S. cochlear percentage cover throughout the lower eulittoral zone from each of the three study sites. 
Figure 5. The habit (A, C) and close-up of the margins (B, D) of the thin and thick forms of S. yendoi from Holbaaipunt and Port Nolloth respectively.

Figure 6. The marginal growth of S. yendoi under natural conditions from each of the three study sites.

Figure 7. The linear relationship between the thallus thickness and the lateral margin extension rate for thick (Holbaaipunt, Groenriviermond, Port Nolloth) and thin (Holbaaipunt, Groenriviermond) forms of S. yendoi.

Figure 8. The marginal growth of S. yendoi under limpet manipulated conditions.

Figure 9. The percentage overgrowth interactions among all intertidal encrusting algae from the three study sites (MESO = Mesophyllum engelhartii; PAPI = Synarthrophyton papillatum; FERO = Leptophytum ferox; YEND = Spongites yendoi; RALF = Ralfsia verrucosa; HILD = Hildenbrandia lecanellierii; PEYS = Peyssonnelia atropurpurea; FOVE = Leptophytum foveatum) and their rank within the competitive hierarchy (1 ranks lowest i.e. overgrown by all other species; 5 ranks highest i.e overgrows all other species). Species separated by the "/" sign are assigned equal ranking because they have not been observed to compete, e.g. S. yendoi and R. verrucosa have not been observed to compete locally at Port Nolloth and so their interaction has been represented by an open bar.

Figure 10.A schematic diagram of the benefits and costs to S. yendoi resulting from the presence and absence of grazing by S. cochlear. 
Figure 1

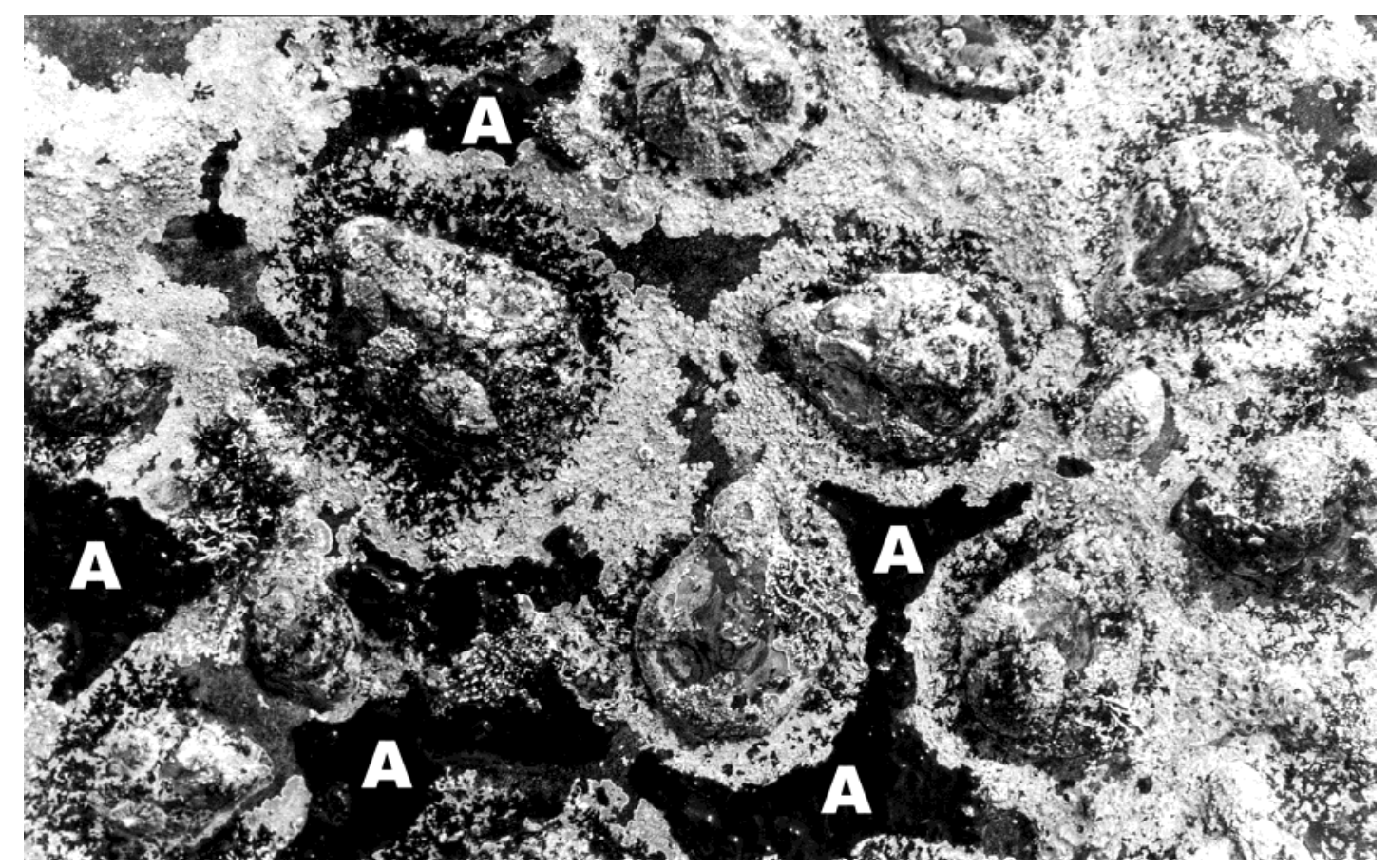

Figure 2

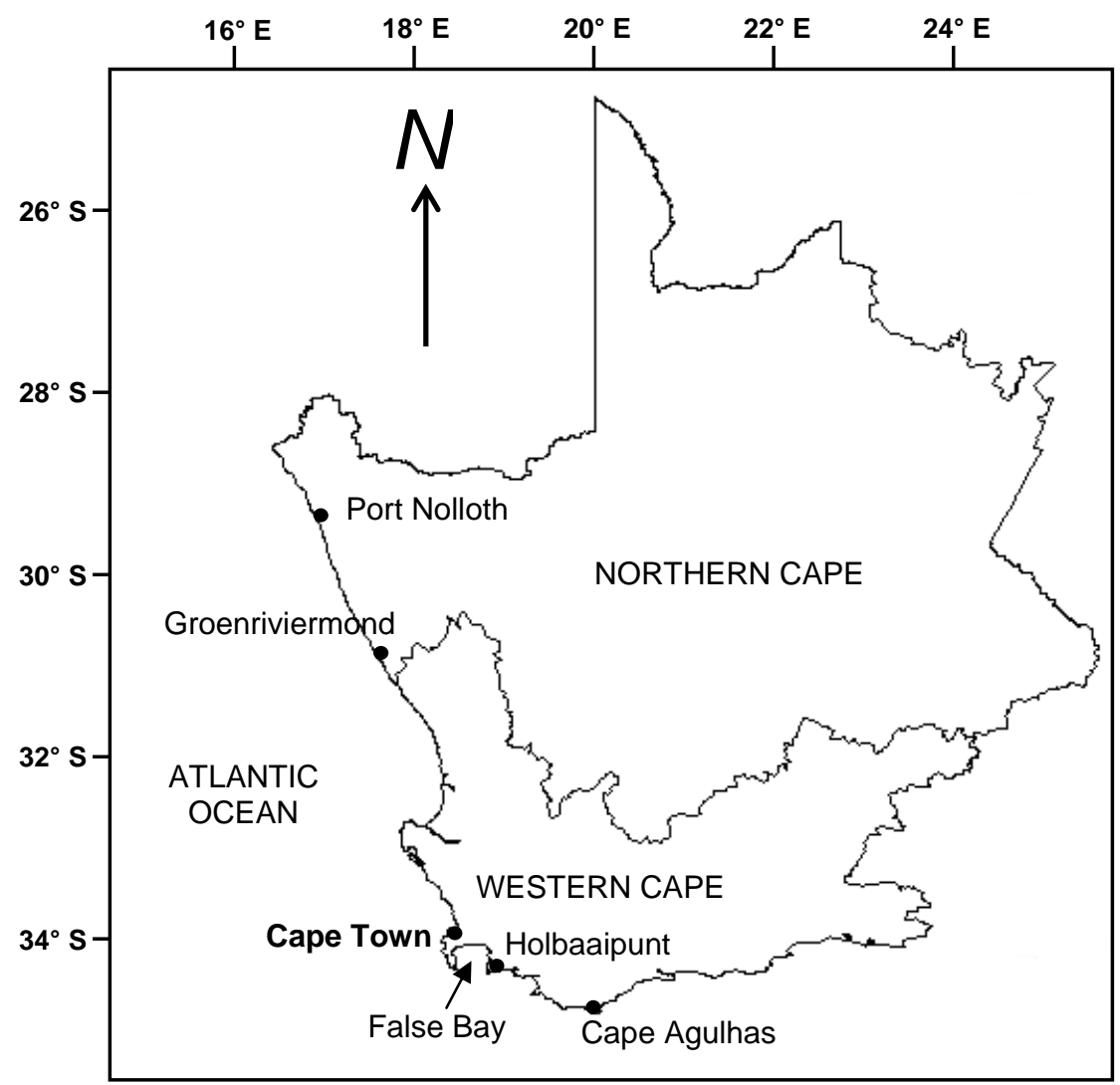


Figure 3

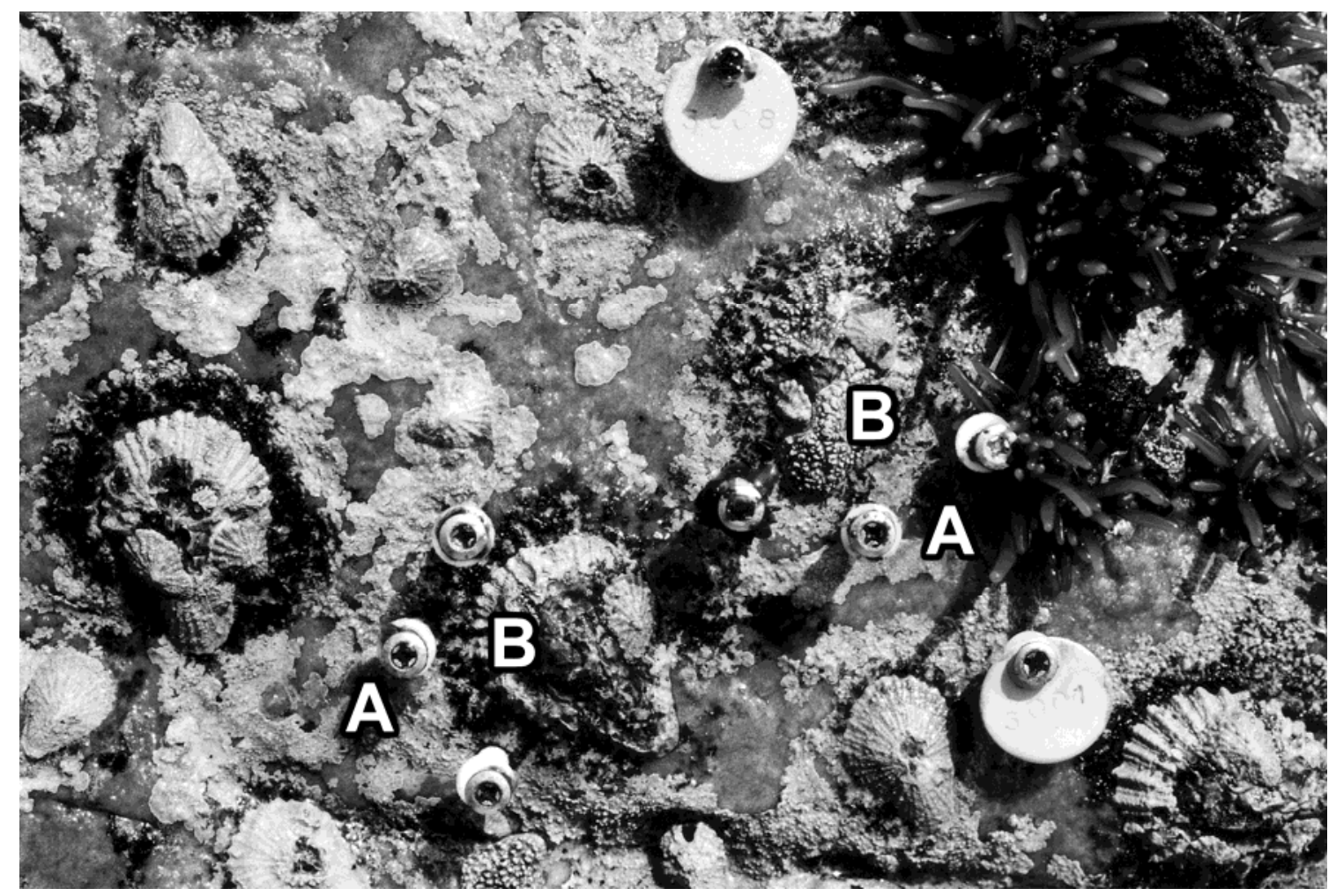

Figure 4

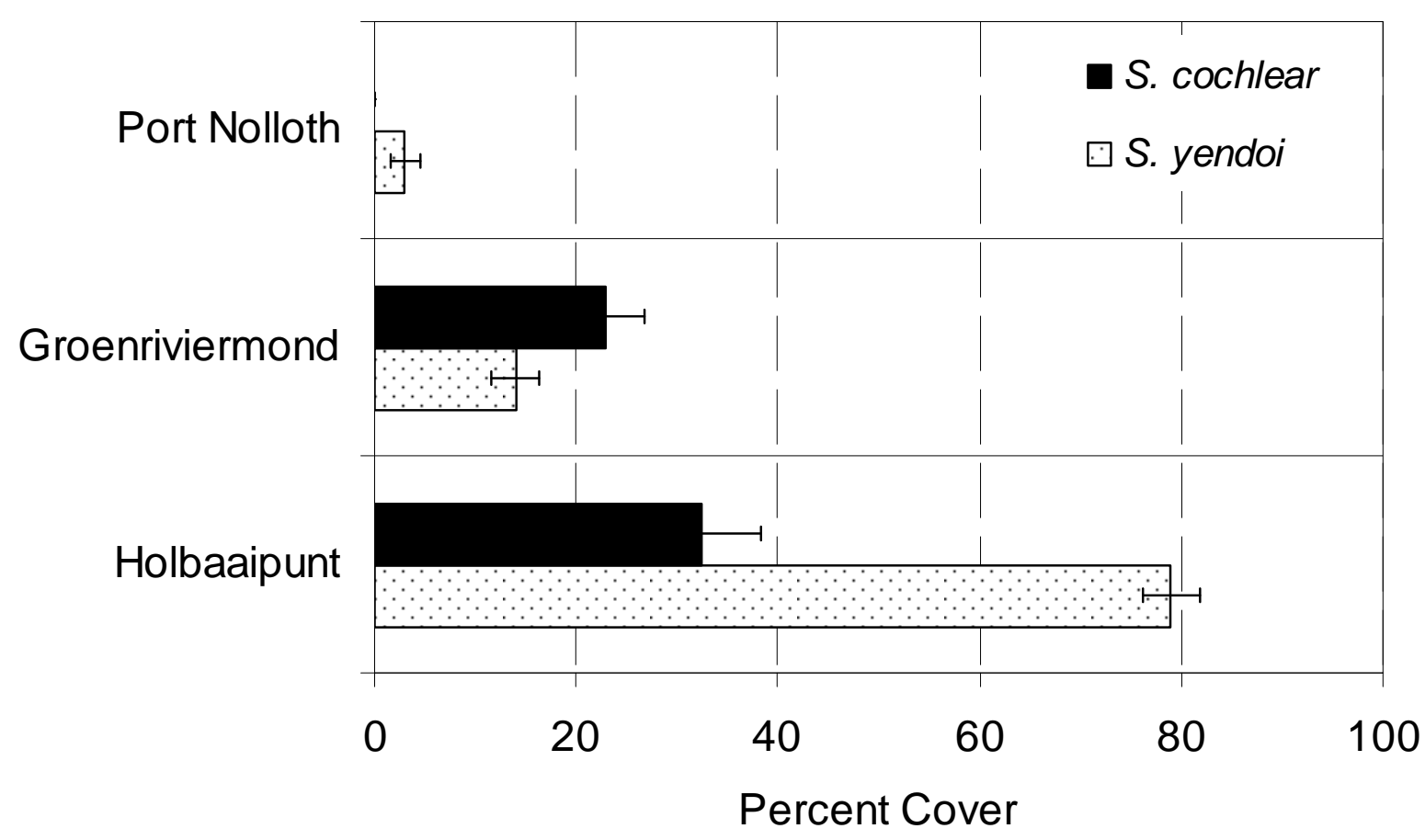


Figure 5
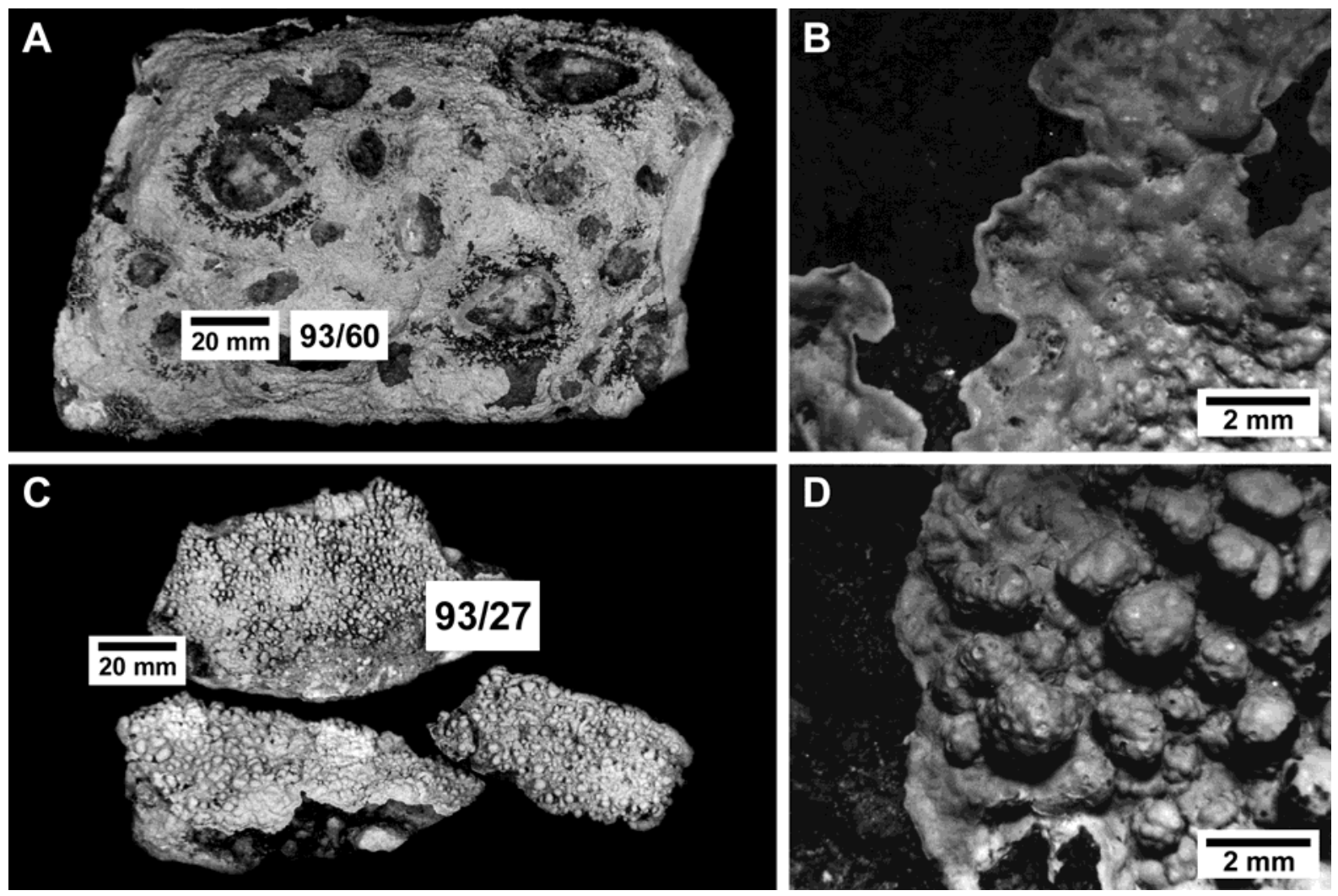

Figure 6 


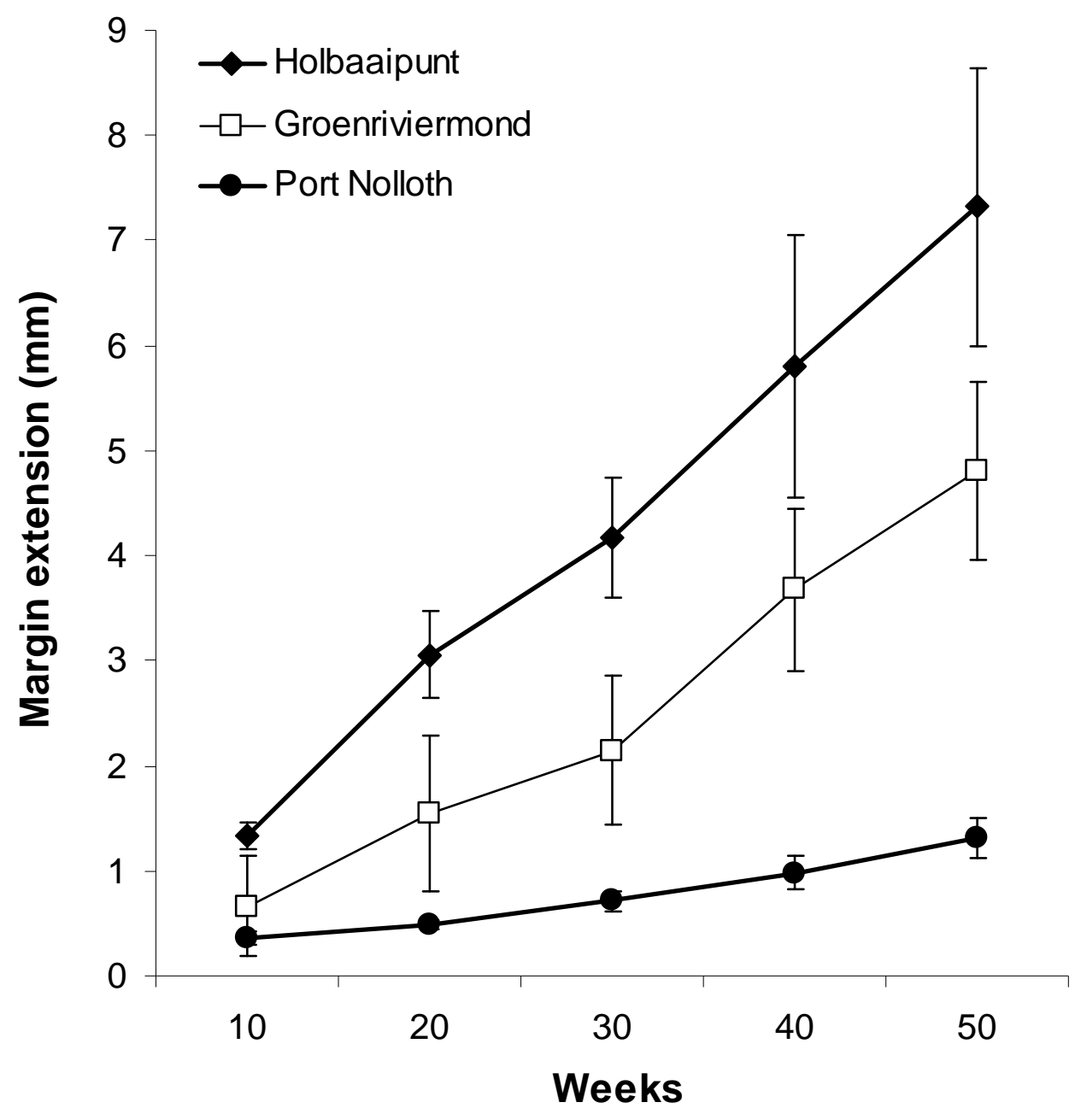

Figure 7 


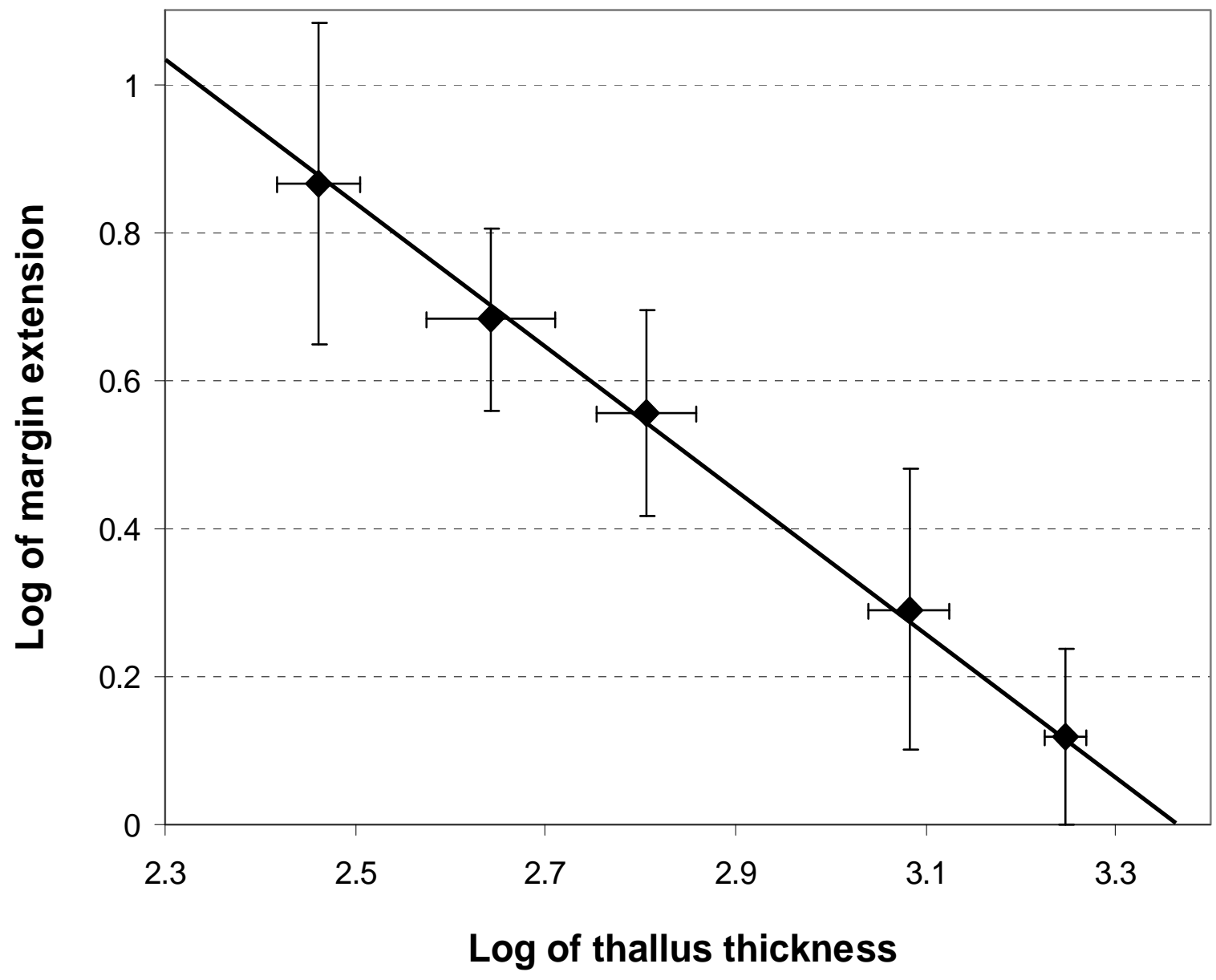

Figure 8 


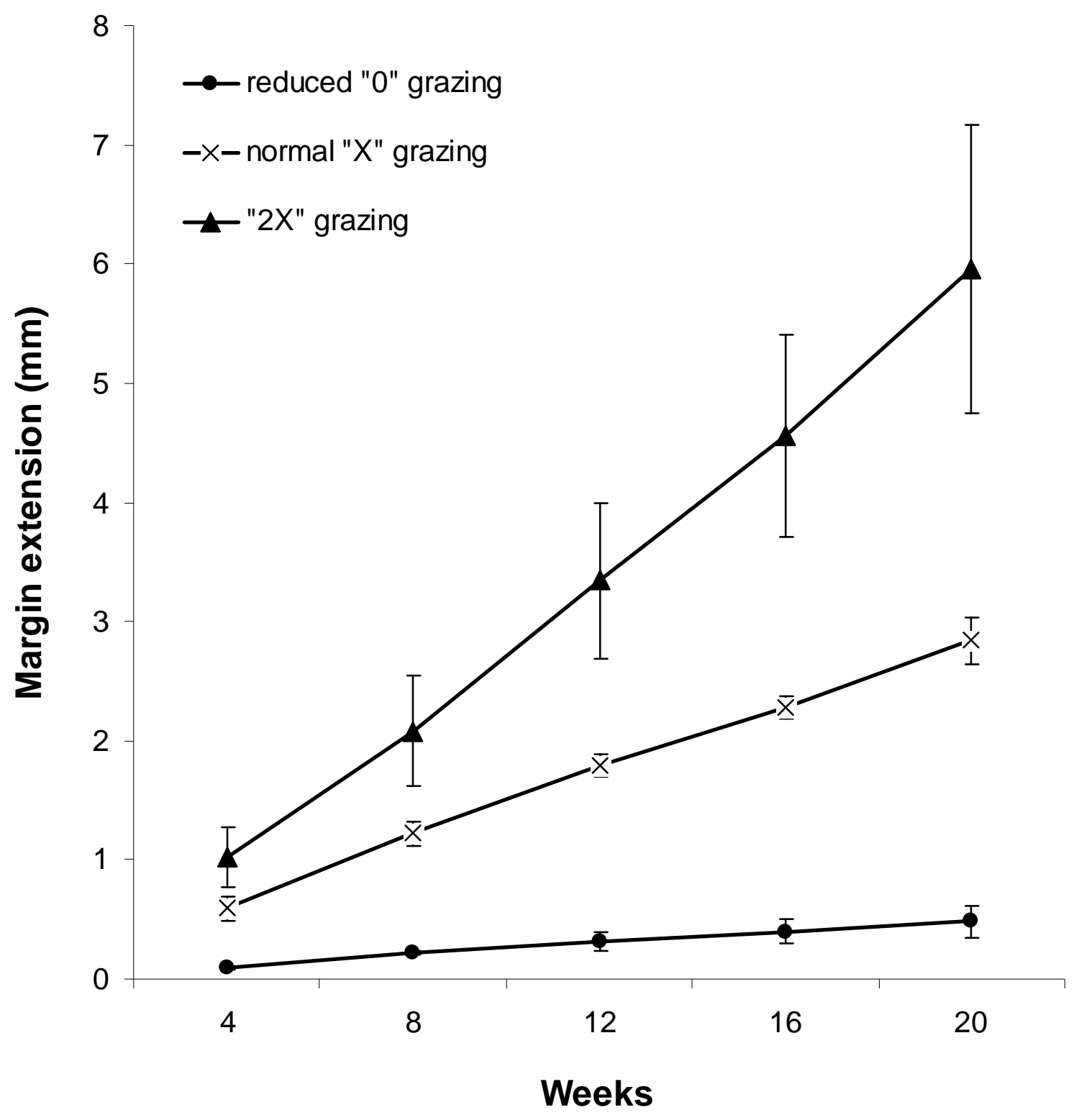

Figure 9 
Holbaaipunt

\begin{tabular}{|l|l|}
\hline \multicolumn{2}{|l|}{ RANKING } \\
\hline MESO & 5 \\
PAPI/RALF & 4 \\
FERO & 3 \\
YEND & 2 \\
HILD & 1 \\
& \\
\hline
\end{tabular}

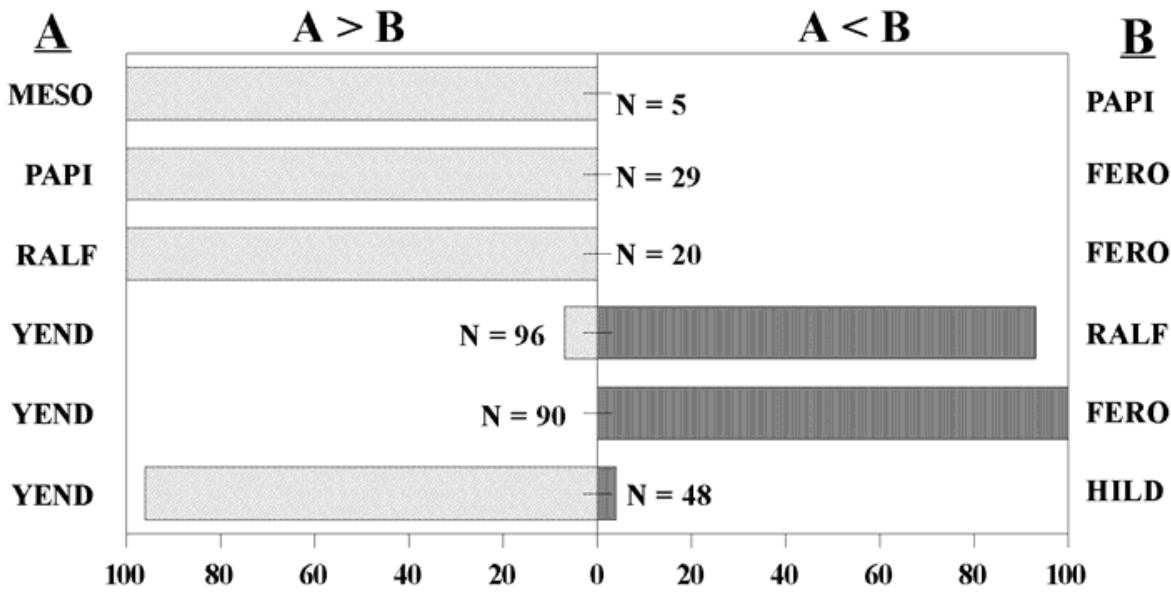

Groenriviermond

\begin{tabular}{|l|l|}
\hline \multicolumn{2}{|l|}{ RANKING } \\
\hline MESO & 5 \\
\hline PEYS / FERO & \\
/ PAPI & 4 \\
YEND & 3 \\
RALF & 2 \\
FOVE / HILD & 1 \\
& \\
\hline
\end{tabular}

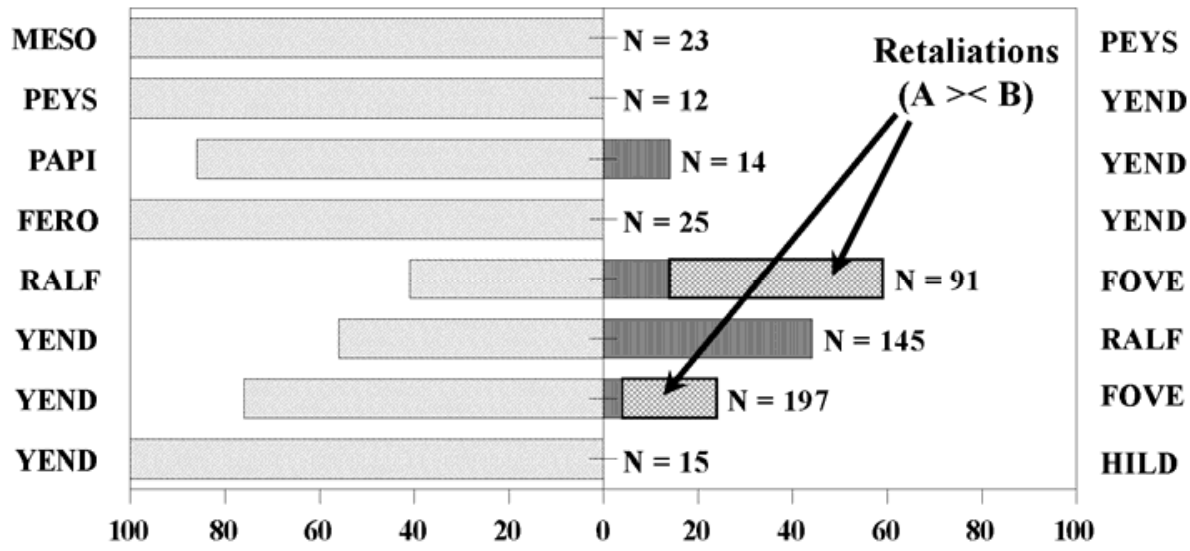

Port Nolloth

\begin{tabular}{|l|c|}
\hline \multicolumn{2}{|l|}{ RANKING } \\
\hline PEYS & 3 \\
YEND / RALF & 2 \\
FOVE / HILD & 1 \\
& \\
& \\
\hline
\end{tabular}

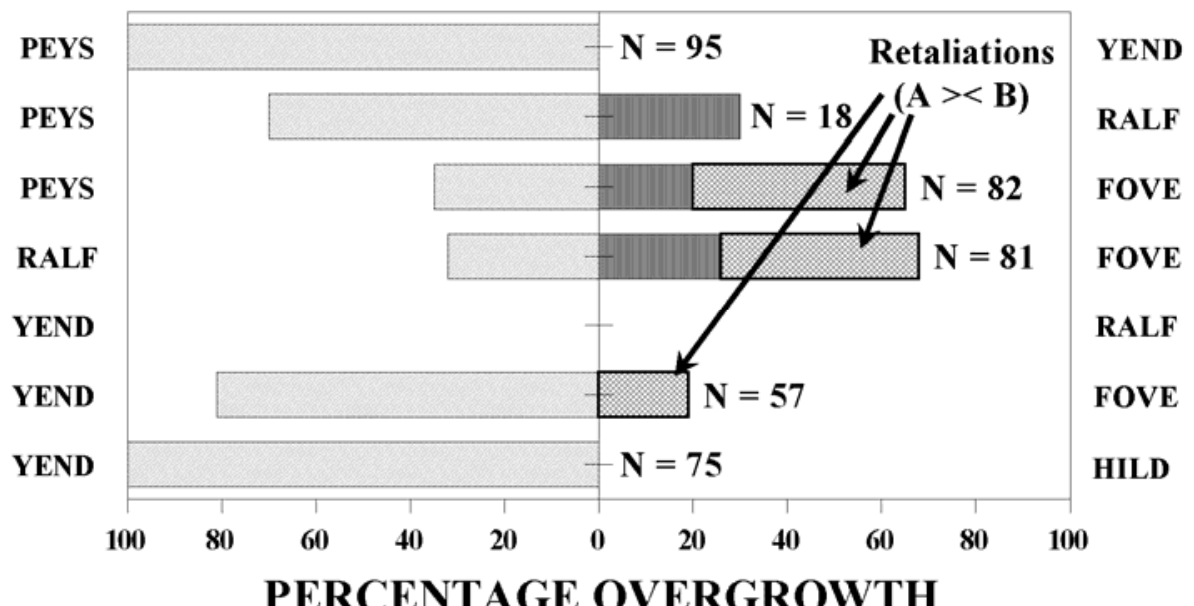


Figure 10

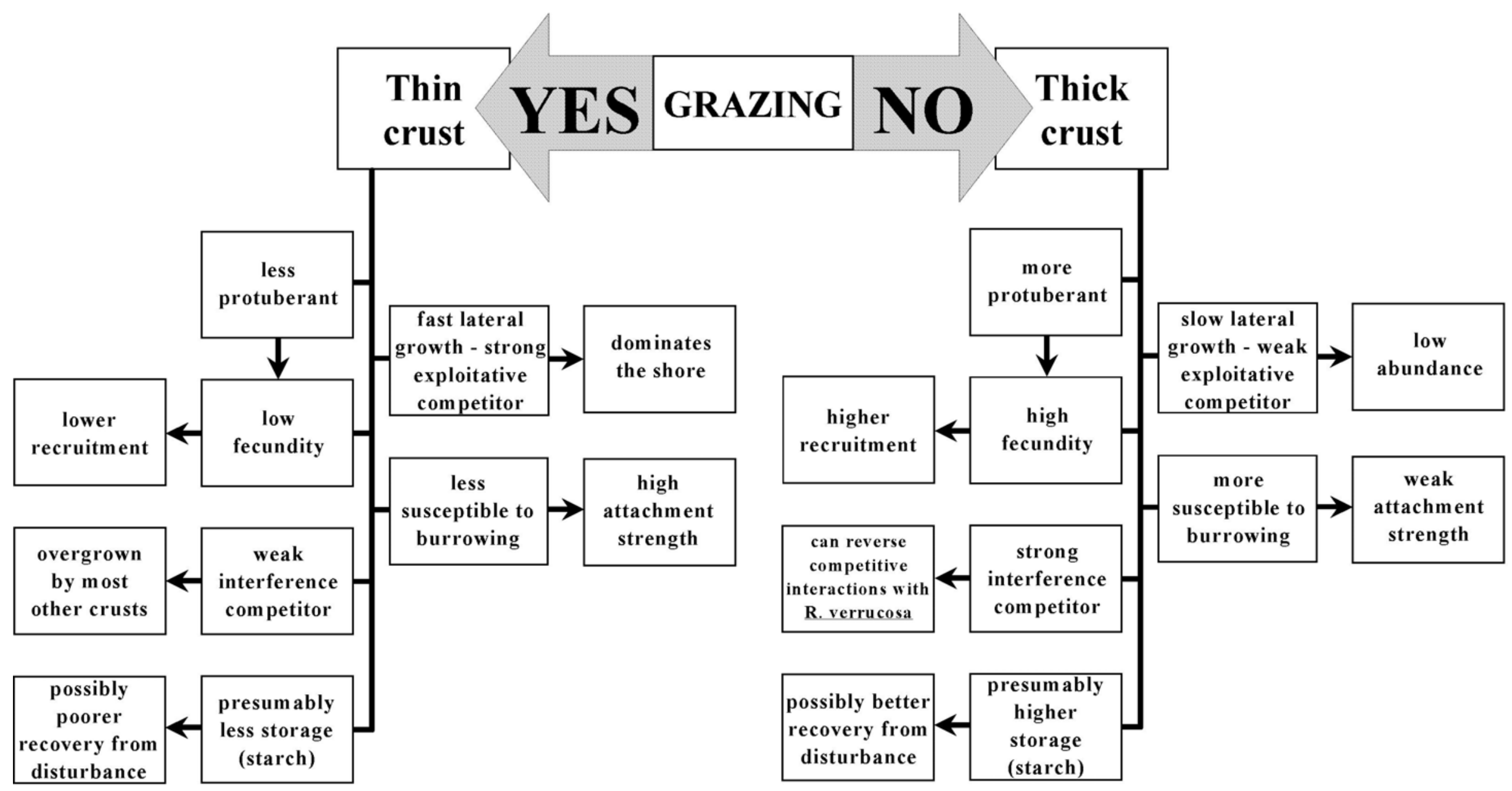

